\title{
Effect of Exercise Preconditioning on Protein Expression of VEGF and NeuN in Rats with Cerebral Ischemia-reperfusion
}

PEI Fei ${ }^{1}$, WANG Xuedong ${ }^{2}$, LI Baolong ${ }^{1}$, TANG Qiang ${ }^{1}$, ZHU Luwen $^{1 *}$

${ }^{1}$ The Second Affiliated Hospital of Heilongjiang University of Traditional Chinese Medicine, Harbin, Heilongjiang 150001, China;

${ }^{2}$ Acupuncture and Tuina College and Rehabilitation College, Heilongjiang University of Traditional Chinese Medicine, Harbin, Heilongiang 150001, China

* Correspondence: ZHU Luwen, E-mail:zhuluwen1983@126.com

ABSTRACT Objective: To explore the effects of exercise preconditioning on the expression of vascular endothelial growth factor (VEGF) and neuronal core antigen (NeuN) proteins in rats with cerebral ischemia-reperfusion. Methods: The rats were randomly divided into sham-operation group, model group, exercise sham-operation group (exercise pretreatment and sham-operation group) and exercise model group (exercise pretreatment and model group) by the random number table method, with 24 rats in each group. Each group was then divided into two subgroups according to the cerebral ischemia-reperfusion time of 24 hours and 3 days, with 12 rats in each subgroup. Before the model was built, the exercise sham-operation group and the exercise model group were trained on the treadmill for 3 weeks. In the model group and exercise model group, the modified Longa suture method was used to prepare the rat middle cerebral artery occlusion (MCAO) model. After 2 hours, the suture was slowly pulled out to the branch of the common carotid artery. The method of modeling rats in the sham-operation group and the exercise sham-operation group was the same as the above, but the thread plug was only inserted about $10 \mathrm{~mm}$ from the common carotid artery and then pulled out, which could not block the middle cerebral artery blood supply. The modified neurologic severity score (mNSS) was used to assess neurological function, while the immunohistochemistry and Western blot were respectively used to determine the protein expression levels of VEGF and NeuN in the ischemic lateral brain tissue. Results: 1) There were no neurological deficits in the sham-operation group and the exercise sham-operation group. Compared with the model group, the neurological deficit scores of the exercise model group at 24 hours and 3 days after cerebral ischemia-reperfusion decreased, and the comparison between the two groups was statistically significant $(P<0.05)$. 2$) 24$ hours after cerebral ischemia-reperfusion, a small amount of VEGF expression were seen in the sham operation group, the positive cell bodies were small, and the protrusions were thin; compared with the positive rate of the exercise model group (14.40\%), the positive rate of the sham-operation group $(4.70 \%)$, the positive rate of the model group $(9.80 \%)$, the positive rate of the exercise sham-operation group $(8.80 \%)$ were low, and the differences were statistically significant respectively $(P<0.05)$. Three days after cerebral ischemia-reperfusion, compared with the positive rate of the exercise model group $(23.80 \%)$, the positive rate of the sham-operation group $(5.40 \%)$, the positive rate of the model group $(12.40 \%)$, and the positive rate of the exercise sham-operation group $(14.20 \%)$ were all reduced, and the differences were statistically significant respectively $(P<0.05)$. 3$) 24$ hours after cerebral ischemia-reperfusion, compared with the exercise model group, the expression of NeuN protein in the model group was less, and the difference was statistically significant $(P<0.05)$; Three days after cerebral ischemia-reperfusion, compared with the exercise model group, the expression of the model group was less, and the difference was statistically significant $(P<0.05)$. Conclusion: Exercise preconditioning before cerebral ischemia- reperfusion can reduce the performance of neurological deficits after cerebral ischemia-reperfusion, and improve sensorimotor dysfunction and motor behavior by enhancing the protein expression of VEGF and NeuN.

KEY WORDS ischemia-reperfusion; vascular endothelial growth factor; neuronal core antigen; exercise preconditioning DOI : $10.3724 /$ SP.J.1329.2021.01006

\section{《康复学报》第二届编委会名单}

主 编：陈立典

副主编：曹丽英吴毅 黄晓琳 黄锦文林克忠敖丽娟

燕铁斌陶静 Alice Y M JONES(澳大利亚)

顾 问: 陈可冀 石学敏 孙塑伦 励建安 彭 斌 周谋望

编 委: (按汉语拼音顺序排列)

\begin{tabular}{|c|c|c|c|c|c|c|}
\hline 陈红霞 & 陈 & 陈锦秀 & 陈文华 & 旸(美国) & 陈友琴(美国) & 月(美国) \\
\hline 卓铭 & 窦祖林 & 冯晓东 & 何 坚 & 胡 & 黄东锋 & 黄国志 \\
\hline 黄惠榕 & 黄建平 & 黄苏萍 & 贾子善 & 姜迎萍 & 金荣疆 & 孔 健(美国) \\
\hline 奎成 & 李 丽 & 廖维靖 & 林国徽 & 林明和 & 刘建忠 & 吕晓东 \\
\hline 牟 翔 & 穆克利 (美国) & 彭 & 邱模炎 & 苏友新 & 唐 强 & 唐 \\
\hline 于领 & 吴民华 & 强 & 谢仁明 & 谢欲晓 & 间彦宁 & 杨 \\
\hline 珊莉 & $\begin{array}{l}\text { 姚新苗 } \\
\text { 字母顺序排列) }\end{array}$ & 余曙光 & 战丽彬 & 张安仁 & 赵文汝 & \\
\hline & & & & 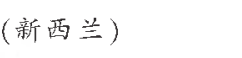 & & \\
\hline & $\operatorname{VES}$ (加拿大) & & & 国) & & \\
\hline
\end{tabular}

